\title{
Knowledge and attitudes influence in implementation of household waste management program
}

\author{
Y. M. Hasibuan ${ }^{1 *}$, F. M. Sidjabat ${ }^{1}$ \\ ${ }^{1}$ Environmental Engineering, President University, Bekasi, Indonesia
}

\begin{abstract}
Abstrak.
Sampah menjadi permasalahan utama yang sering dijumpai pada kota metropolitan seperti DKI Jakarta. Penelitian Dinas Lingkungan Hidup DKI Jakarta menyatakan bahwa DKI Jakarta menghasilkan 7500 ton limbah per hari dengan $60,5 \%$ berasal dari perumahan. Oleh karena itu, pemerintah DKI Jakarta memprakarsai Sampah Tanggung Jawab Bersama (SAMTAMA) untuk memobilisasi penduduk mengelola limbah dari sumbernya di suatu lokasi percontohan yakni RT (Rukun Tetangga) 10 / RW (Rukun Warga) 03 Cempaka Putih Timur. Lokasi ini dianggap optimal dalam mengimplementasikan program SAMTAMA. Penelitian bertujuan mengetahui adanya pengaruh pengetahuan dan sikap terhadap perilaku implementasi program SAMTAMA. Metode yang diterapkan dalam mengukur perilaku menggunakan kuesioner jenis Skala Likert. Regresi linier berganda diaplikasikan pada pengolahan data. Diperoleh bahwa pengetahuan dan sikap memiliki pengaruh terhadap perilaku implementasi program SAMTAMA.
\end{abstract}

\begin{abstract}
.
Waste is one of the big problems often faced by metropolitan cities like DKI Jakarta. The Environmental Agency of DKI Jakarta's research stated that DKI Jakarta produces 7500 tons of waste per day with $60.5 \%$ coming from residential. Therefore, the DKI Jakarta government initiated the "Sampah Tanggung Jawab Bersama" (SAMTAMA) to mobilize residential people to manage waste from its source at certain locations as a pilot, one of the locations is RT 10/RW 03 Cempaka Putih Timur. This location is regarded optimal in implementing the SAMTAMA program. Based on this, study aim was to find out whether knowledge and attitude affect the implementation SAMTAMA program. The method implemented in measuring the behavior using a questionnaire with Likert Scale. Multiple linear regression was applied. Knowledge and attitudes influenced the implementation SAMTAMA program behavior.
\end{abstract}

Keywords: attitude, behavior of implementation, knowledge, multiple linear regression, SAMTAMA

Kata kunci: sikap, perilaku implementasi, pengetahuan, regresi linear berganda, SAMTAMA

\section{INTRODUCTION}

In metropolitan cities, waste management faces many challenges because the quantity of waste is increasing. The increasing waste happens because the management uses the old concept which depends on collection, transportation and disposal activities. According to Environmental Agency of DKI Jakarta Province, if there is no appropriate waste management system, it will take a lot of budget and more landfill location from time to time.

DKI Jakarta is a densely populated area. According to an attachment of Decree of the Head of Sanitation Agency of DKI Jakarta Province Number 334 Year 2013, their research in 2011 stated that DKI Jakarta produced a large amount of organic waste for as much as $53.75 \%$ shown in Table 1.

\footnotetext{
${ }^{*}$ Korespondensi Penulis

Email : mimahsb20@gmail.com
} 
Table 1. DKI Jakarta's waste composition.

\begin{tabular}{clc}
\hline No & Waste composition & Percentage (\%) \\
\hline 1 & Organic (food scraps, leaves, etc.) & 53.75 \\
2 & Inorganic & 14.92 \\
3 & Plastic & 14,02 \\
4 & Paper & 14.02 \\
5 & Glass & 2.45 \\
6 & Metal & 1.82 \\
7 & Fabric/textile & 1.11 \\
8 & Wood & 0.87 \\
9 & Hazardous waste & 0.56 \\
10 & Rubber & 0.52 \\
11 & Building demolition waste & 0.01 \\
12 & Etc. & 9.98 \\
\hline
\end{tabular}

Besides that, according to Environmental Agency of DKI Jakarta Province (2018) in the Integrated Waste Management Unit Official Portal, Jakarta produced 7452.6 tons of waste per day in $2018,60.5 \%$ of which is from domestic waste. In 2022, TPST Bantargebang is predicted being unable to dispose of waste again, if it still uses the old concept.

Concept of waste management that depends on disposal activities should be discarded and substituted by a new concept. DKI Jakarta government has designed a household waste management program named "Sampah Tanggung Jawab Bersama" (SAMTAMA). This program persuades people to manage their own waste, so that not only the government taking the responsibility.

SAMTAMA is a waste management movement/social labelling to reduce or manage the waste by increasing people's awareness. To support the SAMTAMA Program, DKI Jakarta's government gives socializations on each "Rukun Warga" (RW) representatives concerning the waste's awareness by bringing them to see the TPST Bantargebang condition. Besides that, the representatives are equipped with knowledge about 3R (Reduce, Reuse and Recycle) toward the waste, therefore they are able to handle their own waste properly. Currently, the SAMTAMA program regulation is still in progress. This regulation is expected to be able to support the program in order to be sustain.

Currently, DKI Jakarta has 22 RWs as the pilots of SAMTAMA program implementation. RW 03 of Cempaka Putih Timur is regarded as a good example of implementing this program. It has a barrel of composter, cultivation of maggot $\mathrm{BSF}$, and waste bank for food and plastic waste reduction.

To implement the program of SAMTAMA in all DKI Jakarta locations, it requires social aspect optimization by implementing questionnaire. This questionnaire examines variables affecting the implementation SAMTAMA program behavior by applying these tools, such as analysis of description, multiple linear regression and testing of hypothesis. 


\section{METHODOLOGY}

\subsection{Research location and time}

The research location was at Rukun Tetangga (RT) 10 / RW 03 Cempaka Putih Timur, Jakarta Pusat. RT 10 site had 70 houses including 218 inhabitants. This research was carried out in January 2020.

\subsection{Research method}

\subsubsection{Questionnaire preparation}

This was printed with seven groups of the questionnaire. The first group was about questionnaire's objectives and ask respondents to co-operate in completing the questionnaire. The second group had purpose to classify respondent characteristic including age, status and education. The respondent who completes this questionnaire is housewives residing perpetually at RT 10/RW 03 Cempaka Putih Timur. The third group consisted of instructions for the respondents to consider how the questionnaire would be filled in. Groups 4, 5 and 6 were the principal questionnaire applying Likert scale (1-5). Scale 1 was signifying strong disagreement and scale 5 meaning strong agreement. The last group (7) signifies the obstacles and suggestions of SAMTAMA program.

Therefore, this questionnaire had a total question as many as 27 items. Thereafter, 22 questionnaires using Likert scale were verified for validity and reliability by applying an open-source statistical software of PSPP after distribution to 30 persons. 30 is the minimum sample size for evaluating the validity and reliability of questionnaire (Khan et al. 2014).

\subsubsection{Validity test}

A validation conducted in RW 03 Cempaka Putih Timur with a total sample of 30 people who had lived. To test the validity, Pearson Product Moment correlation was applied. Then, application of two-tailed $r$ table containing critical values will convince the significant of $r$ value. For this analysis the $\mathrm{df}$ value was $\mathrm{n}-2$, $\mathrm{n}$ was the sample's number. The null hypothesis (Ho) is rejected when $\mathrm{r}$ is greater than the critical value. This study had 30 samples for validity test, so the critical value used was 0.361007 (Samuels 2017).

\subsubsection{Reliability test}

Reliability test is a tool of determining instruments to identify the accuracy. The tests can always stay accurate when used repeatedly. The Cronbach Alpha method can be used for reliability testing and the following is the categorization (Table 2). 
Table 2. Category of Cronbach Alpha's value.

\begin{tabular}{cc}
\hline Alpha value & Internal reliability \\
\hline$\alpha \geq 0.9$ & Excellent \\
$0.9>\alpha \geq 0.8$ & Good \\
$0.8>\alpha \geq 0.7$ & Acceptable \\
$0.7>\alpha \geq 0.6$ & Questionable \\
$0.6>\alpha \geq 0.5$ & Poor \\
$0.5>\alpha$ & Unacceptable \\
\hline
\end{tabular}

\subsubsection{Descriptive analysis}

Respondent characteristics were examined by considering attitude and knowledge on the implementation of SAMTAMA program behavior. It is done by measuring the frequency of the particular response of respondent. Each question mean was calculated to point out the high, moderate or low level of each variable (Table 3) (Oxford and Burry-Stock 1995).

Table 3. Mean result range interpretations.

\begin{tabular}{cc}
\hline Mean & Explanation \\
\hline$<2.5$ & Low \\
$2.5-3.5$ & Moderate \\
$>3.5$ & High \\
\hline
\end{tabular}

\subsubsection{Multiple linear regression}

The linear regression formula can be seen as follows (Equation 1) (Arikunto 2013).

$y=\beta_{0}+\beta_{1 x 1}+\beta_{2 x 2}+\cdots+\beta_{k x k}+\varepsilon$

Description:

$\beta_{0} \quad=\mathrm{y}$ value when $\mathrm{x}$ is 0 ( $\mathrm{y}$-intercept) $\mathrm{X}=$ independent variable

$\beta_{1} ; \beta_{2} \ldots \beta_{\mathrm{k}}=$ corresponding variable slope $\quad \varepsilon=$ residual terms

$\mathrm{Y} \quad=$ dependent variable

Furthermore, three classical assumption test classifications were used to examine the regression model accuracy, such as the normality, heteroscedasticity and multicollinearity test. A regression model intended to know the normality of data distribution is the meaning of normality test. The test is performed by the Normal Probability-plot (P-plot). When the data is normally distributed, then the diagonal lines will appear in the lines on the graph (Pawirosumarto et al. 2017). Heteroscedasticity test is beneficial for checking the occurrence of inequality variance within residual variance. Supposed the chart signifies a regular form, as a big wave, heteroscedasticity is going to narrow and when the points distribute at the upper and lower the number 0 on $\mathrm{Y}$ axis without establishing a particular form, hence, no heteroscedasticity (Indriaty 2010). Test of multicollinearity are carried out by rivalling the variance inflation 
factor (VIF) to the appropriate value. All three tests have been analyzed by Microsoft Excel (Pawirosumarto et al. 2017).

\subsubsection{Hypothesis testing}

This study used three methods to test the hypothesis such as, F-test, T-test and R-squared. Microsoft Excel performed the test. The F-test indicates level of significance of independent toward dependent variable (Archdeacon 1994). Ttest revealed substantial difference in group mean level (Archdeacon 1994). The $\mathrm{R}$-squared test is valuable for hypotheses testing to show the model equation of this study (Draper and Smith 1998).

\section{RESULT AND DISCUSSION}

\subsection{Descriptive analysis}

Age and education level are the respondent's characteristics measured in this research. From 35 respondents, this research was mainly the age group of $\leq$ 45 (12.34\%) (Table 4) and high school education group (20.57\%) (Table 5).

Table 4. The respondent's characteristic based on age.

\begin{tabular}{clc}
\hline No & Age range (year) & Percentage $(\%)$ \\
\hline 1 & $\leq 45$ & 12.34 \\
2 & $46-50$ & 8.23 \\
3 & $51-55$ & 4.12 \\
4 & $56-60$ & 5.14 \\
5 & $\geq 60$ & 6.17 \\
\hline
\end{tabular}

Table 5. The respondent's characteristic based on education level.

\begin{tabular}{clr}
\hline No & Education level & Percentage (\%) \\
\hline 1 & Elementary & 2.60 \\
2 & Junior High School & 7.20 \\
3 & Senior High School & 20.57 \\
4 & Diploma & 4.11 \\
5 & BSc & 2.60 \\
6 & MSc & 0 \\
7 & Doctor & 2.60 \\
\hline
\end{tabular}

The description of three questionnaire variables can be seen in the Table 6. Each question generated mean value of above 4 . Average value below 4 was represented by 3 questions meaning that the respondents understand the SAMTAMA. For further analysis it was carried out Validity and Reliability Test.

Table 6. Mean test result.

\begin{tabular}{cccccccc}
\hline \multirow{2}{*}{ Variables } & \multirow{2}{*}{ Labels } & \multicolumn{7}{c}{ Frequency } & \multirow{2}{*}{ Mean } \\
\cline { 3 - 7 } & 1 & 0 & 0 & 0 & 17 & 18 & 4.51 \\
& 2 & 0 & 1 & 0 & 21 & 13 & 4.31 \\
$\mathrm{~A}$ & 3 & 0 & 3 & 0 & 20 & 12 & 4.17 \\
\hline \multirow{3}{*}{$\mathrm{B}$} & 1 & 0 & 1 & 2 & 16 & 16 & 4.34 \\
& 2 & 0 & 0 & 1 & 25 & 9 & 4.23 \\
& 3 & 0 & 0 & 1 & 27 & 7 & 4.17 \\
& 4 & 0 & 8 & 17 & 8 & 2 & 3.11 \\
\hline
\end{tabular}




\begin{tabular}{cccccccc}
\hline \multirow{2}{*}{ Variables } & \multirow{6}{*}{ Labels } & \multicolumn{7}{c}{ Frequency } & \multirow{2}{*}{ Mean } \\
\cline { 2 - 6 } & 5 & 0 & 0 & 3 & 22 & 10 & 4.20 \\
& 6 & 0 & 1 & 2 & 23 & 9 & 4.14 \\
& 7 & 0 & 0 & 1 & 20 & 14 & 4.37 \\
\hline \multirow{2}{*}{$\mathrm{C}$} & 1 & 0 & 2 & 1 & 24 & 8 & 4.09 \\
& 2 & 0 & 4 & 2 & 17 & 12 & 4.06 \\
& 3 & 0 & 4 & 3 & 19 & 9 & 3.94 \\
& 4 & 0 & 7 & 6 & 15 & 7 & 3.63 \\
\hline
\end{tabular}

Notes:

A : Knowledge

B : Attitude

C : Behavior of implementation SAMTAMA

$1:$ Strongly disagree
$2:$ Disagree
$3:$ Neutral
$4:$ Agree
$5:$ Strongly agree

1 : Strongly disagree

2 : Disagre

5 : Strongly agree

\subsection{Validity test}

Among 22 inquiries, 14 questions were valid, because of $r$ exceeding 0.361007 , so that 14 questions underwent further examination.

\subsection{Reliability Test}

If the Cronbach Alpha value is bigger than $r$ table, a questionnaire will be reliable (Budi 2005). The reliability will show high, if the value of $r$ approaches 1 (Wahyuni 2014). The questionnaire was still acceptable according to the Cronbach Alpha Value categories (Table 7).

Table 7. Reliability statistics result.

\begin{tabular}{ccc}
\hline N of items & Cronbach's Alpha & Internal consistency \\
\hline 22 & 0.73 & Acceptable \\
\hline
\end{tabular}

\subsection{Multiple linear regression}

According to multiple linear regression, this research equation model (Equation 2) was:

Implementation SAMTAMA program behavior $=-6.370+0.178$ Knowledge +0.692 Attitude

There were three assumption tests after multiple linear regression analysis. The data were normally distributed according to the normality test (Figure 1). The pattern was spreading in the upper and lower 0 number on the $\mathrm{Y}$ axis without creating a particular pattern, therefore no heteroscedasticity (Figure 2). Then multicollinearity test indicates that all variables had VIF less than 10, meaning accepted (Table 8). 


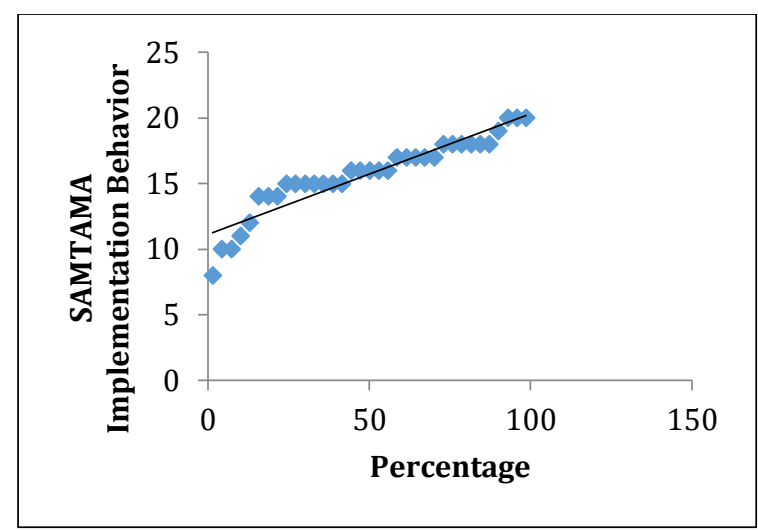

Figure 1. The result of normality test.

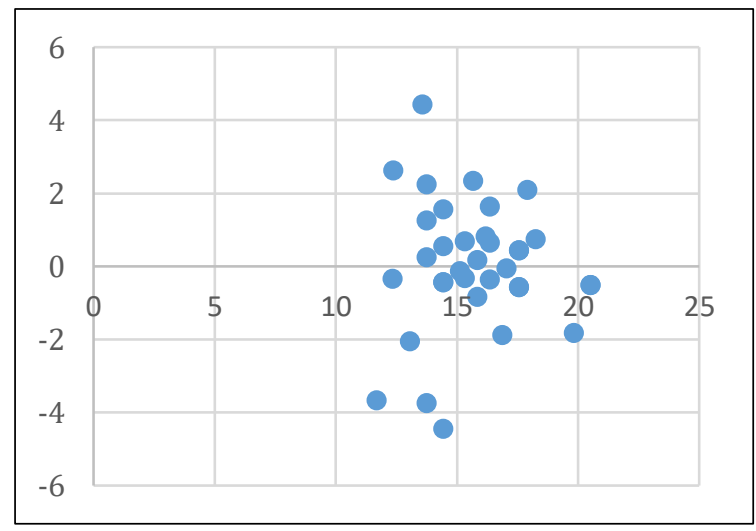

Figure 2. Heteroscedasticity test result.

Table 8. VIF result.

\begin{tabular}{cccc}
\hline Variable & VIF $\left(1 /\left(1-\mathrm{R}^{2}\right)\right.$ & Std & Comment \\
\hline Knowledge & 1.895082480 & $<10$ & Ok \\
Attitudes & 1.895082480 & $<10$ & Ok \\
Behavior & 2.493106694 & $<10$ & Ok \\
\hline
\end{tabular}

\subsection{Hypothesis testing}

According to the multiple linear regression equation discussed above, the result had a negative value of -6.370 , so that the intercept value was not significant, while knowledge and attitudes were significant. The equation model was acceptable with a P-value below 0.05 which is $4.4889 \times 10^{-7}$. Negative numbers intercept could be ignored, therefore it could be assumed to be 0 , because the normality test, heteroscedasticity test, VIF result and ANOVA F-Test values already fulfilled multiple linear regression assumption (Dougherty 2002). For this study, it will create a new type of equation model (Equation 3):

Implementation SAMTAMA program behavior $=0.178$ Knowledge +0.692 Attitude. 
From the above equation it showed that if the value of knowledge increase, it increases the behavior as many as 0.178 of each increment, while if the attitude value increase, it will increase the behavior as many as 0.692 of each increment. Based on that, it was claimed that attitude had more influence on behavior than knowledge. As many as $57.38 \%$ of R-squared test indicated that implementation of SAMTAMA program behavior was affected by knowledge and attitude.

Mean test showed that knowledge had a value of 4.33 ranging 4.17-4.51. Contrasted with mean test interpretation, knowledge had a crucial role in the implementation of SAMTAMA program behavior because of the value $>3.5$. Knowledge is one of the most significant factors affecting behavior (Tekin and Gunes 2018). Due to the value of the mean test results of 4.08 was $>3.5$ ranging 3.11-4.37, this research stated that attitudes also had a crucial role in implementation SAMTAMA program behavior. Moreover, the result of mean value was 3.93 , it was nearly meeting the specified standard minimum. In general, the people put into action SAMTAMA program, hence it has not yet been thoroughly dispersed.

Knowledge and attitude affected the implementation SAMTAMA program behavior. They require also knowledge and attitudes increment to up turn the implementation of SAMTAMA program behavior.

\section{CONCLUSION AND RECOMMENDATION}

It can be concluded that from multiple linear regression, knowledge and attitude are both influencing the behavior of implementation. But in this case, the attitude has a more influence rather than the knowledge, so that the government should pay attention to find the idea or activity to increase the attitude of people in DKI Jakarta towards to SAMTAMA program.

\section{ACKNOWLEDGEMENT}

The authors would thank our colleagues in President University who gave us feedback and assistance during the research. Also, we thank you to Environmental Agency of DKI Jakarta Province, Mrs. Rita Ningsih who gave us permissions to do this research and Mr. Adian Sudiana in RT 10/RW 03 Cempaka Putih Timur who always helped us to conduct this research.

\section{REFERENCES}

Archdeacon TJ. 1994. Correlation and Regression analysis: a historians guide. University of Wisconsin Press. Madison.

Arikunto S. 2013. Prosedur penelitian. Rineka Cipta. Jakarta. Budi TP. 2005. SPSS 13.0 terapan. CV Andi Offset. Yogyakarta. 
Decree of the Head of Sanitation Agency of DKI Jakarta Province Number 334 Year 2013.

Dougherty C. 2002. Introduction to econometrics. Oxford University Press. Oxford.

Draper NR and Smith H. 1998. Applied regression analysis third edition (wiley series in probability and statistics). Wiley-Interscience. United States of America.

Environmental Agency of DKI Jakarta Province. 2018. Data-data TPST Bantargebang [internet]. Available at: https://upst.dlh.jakarta.go.id/tpst/ data.

Indriaty DR. 2010. Analisis pengaruh tingkat kualitas pelayanan jasa puskesmas terhadap kepuasan pasien (studi pada Puskesmas Gunungpati Semarang) [Undergraduate Thesis]. Department of Management, Faculty of Economy and Business, Diponegoro University. Semarang.

Khan YK, Sarrif A, Khan AH and Mallhi TH. 2014. Knowledge, attitude and practice (KAP) Survey of osteoporosis among students of a tertiary institution in Malaysia. Tropical Journal of Pharmaceutical Research 13(1):155-162.

Oxford RL and Burry-Stock JA. 1995. Assessing the use of language learning strategies worldwide with the ESL/EFL version of the strategy inventory for language learning (SILL). System 23(1):1-23.

Pawirosumarto S, Sarjana PK and Muchtar M. 2017. Factors affecting employee performance of PT. Kiyokuni Indonesia. International Journal of Law and Management 59(4):602-614.

Samuels P. 2017. Advice on reliability analysis with small samples - revised version [Technical Report]. Department of Management, HR and Enterprise, Birmingham City Business School, Faculty of Business, Law and Social Sciences, Birmingham City University. Birmingham.

Wahyuni N. 2014. Uji validitas dan reliabilitas [internet]. Available at: https://qmc.binus.ac.id/2014/11/01/u-j-i-v-a-l-i-d-i-t-a-s-d-a-n-u-j-i-r-el-i-a-b-i-l-i-t-a-s/.

Tekin C and Gunes G. 2018. Environmental awareness in university students and the affecting factors. International Journal of Community Medicine and Public Health 5(2):422-429. 